\title{
The Equity of the Executive: Fairness in Tax Law in Nineteenth-Century England
}

\author{
Chantal Stebbings ${ }^{1}$
}

\section{INTRODUCTION}

To a lawyer of the common law tradition, equity is immediately understood as that system of law aimed at mitigating the rigours of the common law, founded on its own distinct principles and coming into discrete existence from the sixteenth century. It developed in England when the original legal system failed to provide for the needs of society. Equity developed as a system of supplementary rules, doctrines and procedures to rectify the deficiencies of the common law and address the injustices that were caused by its inflexible application. ${ }^{2}$ It developed not into a self-contained code, but piecemeal and as a complement to the common law: primarily, though not solely, the common law of property. Although it was derived from the imperatives of conscience, it came to contain a body of settled doctrines and rules, developed by judges who were constitutionally empowered to do so, and administered in what in constitutional terms were courts of law. As such, equity became an integral and legitimate part of the English legal system. "Equity", therefore, referred to both (i), in a technical sense, a body of law and (ii), in a wider sense, the underlying purpose of that body of law: to achieve fairness. These traditional meanings of equity still pervade English law. Outside the realm of law, however, the term has a different and less specialised meaning, though one which includes the original essence of what will be referred to as 'legal

\footnotetext{
${ }^{1}$ Professor of Law and Legal History, and Director of the Bracton Centre for Legal History Research, University of Exeter, UK. The support of the Wellcome Trust for aspects of this research is gratefully acknowledged.

2 F.W. Maitland, Equity (Chaytor A.H. and Whittaker W.J. eds; revsd edn by John Brunyate) (Cambridge University Press, 1949) pp. 1-22.
} 
equity'. It encompasses, essentially, notions of fairness, equality, impartiality and evenhanded dealing. ${ }^{4}$ In tax law, singular in so many ways within the British legal system, the primary perception of the term equity was traditionally in its original wider non-technical sense. Of course, tax law and tax lawyers had to deal with equity in the legal sense - the equity associated with the Court of Chancery - when addressing such matters as the taxation of equitable interests and the tax position of trustees, but it was not legal equity which pervaded the consciousness of the legal regime of tax in its formative period. ${ }^{5}$ The rhetoric of tax in the eighteenth and nineteenth centuries reveals constant references to the equity of specific taxes or taxation in general. And in this context, equity meant, above all, fairness, quite apart from Chancery equity.

In the long nineteenth century, when the legal foundations of the modern British tax system were constructed and refined, the formal legal methods whereby it was sought to achieve this kind of non-technical equity were found to be incapable of ensuring comprehensive fairness. As a result there developed - coeval with the enactment of all tax legislation - a discrete body of informal rules emanating from the revenue departments of the executive aimed at achieving the fair treatment of taxpayers within the intense formalism of the legal system of tax. ${ }^{6}$ This body of rules is called for the purposes of this chapter 'executive equity.' This raft of discretionary decisions as to the application or meaning of statutory charging provisions arrived at exclusively in order to make the tax system operate fairly, namely to create a consistency of treatment within a specific taxable group and to ensure there was no individual hardship, was part of a wide body of rules and guiding principles which was known as 'practice.' The development of most revenue

\footnotetext{
${ }^{4}$ Gary Watt, Equity Stirring, (Hart Publishing, Oxford, 2012) pp. 36-45 This work reflects a growing interest in how other disciplines regard Equity; Alastair Hudson, Equity and Trusts $7^{\text {th }}$ edn (Routledge, London, 2013) pp. 1314-17.

5 This perception has proved enduring. A tax lawyer asked to discuss equity would probably immediately think in terms of 'vertical' and 'horizontal equity' in tax rather than in terms of traditional legal Equity: see Anthony C. Infanti, ‘Tax Equity,' 55 Buffalo Law Review 1191-1260 (2007-8). ${ }^{6}$ Cf legal Equity: Alastair Hudson, Equity and Trusts $7^{\text {th }}$ edn (Routledge, London, 2013) pp. 1302-1319.
} 
'practice' was not motivated by considerations of fairness, but pragmatically driven by urgent administrative necessity to implement the tax laws and make the tax system workable on a daily basis so as to raise the anticipated public revenue and thereby to ensure the revenue authorities fulfilled their statutory duties. While both facets of revenue practice reveal the nature of the interface between the tax executive and formal law, executive equity is of particular interest not only because it is rarely addressed as a discrete element in revenue practice, but because ultimately - unlike revenue practice driven purely by administrative necessity - it was found to be legally unacceptable. ${ }^{7}$

In exploring the nature of executive equity, this chapter aims to see why and how in the nineteenth century these informal practices rapidly came to have significant authority within the legal system of tax and how, by the end of that century, they had acquired a status and authority within that system analogous to legal Equity in the sense that it was regarded by the revenue authorities and the taxpaying public as of equal importance to formal law. It examines the legal and bureaucratic conditions of the nineteenth century, as well as contemporary views of fairness in tax, to assess why executive equity was necessary and why it became of such importance and authority in tax that it gave rise to profound legal questions as to its legitimacy and control to be addressed by judges and legal scholars in the following century. The chapter concludes with an assessment as to how the place of executive equity in the legal framework of tax in the nineteenth century promoted and exacerbated the isolation of tax law within the British legal system.

\footnotetext{
7 In R (Wilkinson) $v$ IRC [2003] 1 WLR 2683, upheld [2005] 1 WLR 1718 (HL), it was held that the revenue authorities could not legitimately exercise their powers so as to grant extra-statutory concessions on the basis of 'general equity between men and women' ([2005] 1 WLR 1718 at 1725 per Lord Hoffman).
} 


\section{FAIRNESS IN TAX}

Fairness in tax, a notion which is informed by contemporary culture and values and accordingly differently conceived at different periods, has been of constant and immense importance to the law and administration of tax. Fairness - however it was conceived - is crucial because of the fiscal imperative of compliance. Taxes have never been popular, but by the early nineteenth century a balance had been achieved between people's dislike of paying taxes and people's appreciation that they owe an underlying public duty to do so. The balance was, however, somewhat fragile. Although taxpayers had no unambiguous right to a 'fair' tax, if they perceived a tax as unfair according to the model of a fair tax accepted at the time, then there existed the very real danger of non-compliance. Noncompliance, namely outright refusal to pay on a widespread scale, the articulation of popular resentment, or widespread evasion, endangered the yield. Yield was the sole measure of the success or failure of a tax. Yield depended on compliance; compliance depended on popular acceptance of a tax; and popular acceptance depended on the perception of a tax as fair. ${ }^{8}$

The meaning of fairness in tax was, and remains, fluid. By the end of the eighteenth century in Britain, however, the malleable notion of fairness in tax had acquired certain stable features which it continued to exhibit, and which were widely understood, until well into the twentieth century. It related to a number of facets of taxation: tax as an institution; the characteristics of taxes; the substance of taxes; and the administration of taxes. John Locke had maintained that the concept of taxation was morally justifiable, constituting a fair contribution to the expenses of managing the state and a key element in the social contract. ${ }^{9}$

\footnotetext{
${ }^{8}$ The Poll Tax of the 1980s is an example of a tax which was perceived as unfair and was rejected by the taxpaying public.

${ }^{9}$ For Locke's theory of social contract, see Jane Frecknall Hughes, 'The Concept of Taxation and the Age of Enlightenment' in John Tiley (ed.), Studies in the History of Tax Law vol. 2 (Hart Publishing, Oxford 2007), pp. 261-3.
} 
Below this highest conception of fairness in taxation there existed a number of general principles of good taxation, developed by Adam Smith and the other classical economists, including the view that taxes should be as light a burden on production as possible, that they should be easy and as cheap as possible to collect, and that they should be certain and equal. ${ }^{10}$ These were the underlying broad tenets of a good - and, implicitly, a fair - tax, ${ }^{11}$ and although the notion of fairness in taxation was to change in other ways, these tenets became central to the theory of modern taxation. A greater degree of specificity in the concept of fairness was provided by another tier of canons of taxation which gave British taxation its particular legal character. They required taxes to be voluntary and necessary in substance, and, in their implementation, non-inquisitorial and administered by agencies outside central government. Taxes were voluntary ${ }^{12}$ if they were submitted to as a matter of choice, for example by choosing not to purchase a commodity which was subject to tax. As to the question of necessity, direct taxes were understood to be such a potent instrument in the hands of central government that they had to be required by an extraordinary national emergency. A tax was non-inquisitorial if it respected deeply-held notions of privacy by ensuring its administration did not require physical encroachment on private property or the exposure of private financial affairs. Finally, if direct taxes were assessed and collected by the local representatives of the taxpayers themselves - persons unconnected with central government and free from its control or influence - the taxpayer would be protected from illegal encroachment by the Crown.

\footnotetext{
10 Adam Smith, An Inquiry into the Nature and Causes of the Wealth of Nations, (R. H. Campbell, A. S. Skinner, W. B. Todd eds., 2 vols. (Clarendon Press, Oxford, 1976), vol. ii, Book V Chapter 2, pp. 825-8; J. S. Mill, Principles of Political Economy 6th edn, People's Edition (Longmans, Green \& Co, London, 1896), Book V, pp. 483-485. See too H. Lloyd Reid, The British Tax-Payers' Rights (T. Fisher Unwin, London, 1898), p. 210.

${ }^{11}$ Notions of fairness pervaded contemporary debate on taxation: Arthur Herald, The Income Tax in Utopia (Garden City Press Ltd, Letchworth, 1917), p. 5.

${ }^{12}$ See the speech of Sir William Pulteney in the debate on the income tax in 1798, Parliamentary History vol.34, 22 Dec. 1798, cols. 134-5; see too William Phillips, 'The Origin of Income Tax,' (1967) British Tax Review 113-26.
} 
The fact of taxation being accepted, in the late eighteenth and early nineteenth centuries the canons of taxation comprehensively addressed the question of fairness in a tax. Objections to new taxes or the reform of established ones almost invariably reflected the undermining of one of the specific canons. For example, the 'triple assessment' of $1798{ }^{13}$ was vehemently resisted: being based entirely on past expenditure, it broke the principle of voluntarism. That criticism was equally directed at the new income tax introduced the following year. ${ }^{14}$ Fierce resistance met all new taxes which were perceived as inquisitorial and invasive. The window and house taxes of the eighteenth century were regarded as excessively intrusive since government officers were permitted to enter houses and gardens for the purpose of taxation, and the principal objection to the income tax in 1799 was its unequivocally inquisitorial nature. ${ }^{15}$ The reintroduction of the income tax in 1842 in a time of peace was condemned for breaching the canon of necessity. Excise duties had always been resented due to their administration entirely by officers of central government, ${ }^{16}$ and when in the later years of the nineteenth century the principle of localism in the administration of income tax was being undermined by the officials of central government, the objections were intense. ${ }^{17}$

In the nineteenth century, however, the traditional canons for ensuring fairness diminished in importance. The requirements that direct taxes should be necessary and

\footnotetext{
1338 Geo. III c. 16 (1798).

1439 Geo. III c. 13 (1799). For the history of income tax, see B. E. V. Sabine, A History of Income Tax (George Allen \& Unwin Ltd, London, 1966); Peter Harris, Income Tax in Common Law Jurisdictions, Cambridge Tax Law Series (Cambridge University Press, 2006); B. E. V. Sabine, 'Great Budgets: Pitt's Budget of 1799', (1970) British Tax Review 201; Thirteenth Report of the Commissioners of Inland Revenue, House of Commons Parliamentary Papers [hereafter HCPP] (1870) (C. 82, 82-1) xx 193, 377 at pp. 326-7.

${ }^{15}$ C. Stebbings, 'The Budget of 1798: Legislative Provision for Secrecy in Income Taxation' British Tax Review (1998) 651. But see too William Phillips, 'The Real Objection to the Income Tax of 1799,' (1967) British Tax Review 177-86.

${ }^{16}$ Michael J. Braddick, 'Popular Politics and Public Policy: the Excise Riot at Smithfield in February 1647 and its Aftermath', 34 Historical Journal 597 (1991); Stephen Matthews, 'A Tax Riot in Tewkesbury in 1805', (2002) British Tax Review 437.

17 See, for example, C. Stebbings, 'A Local Tax Rebellion: Popular Perceptions of Income Tax Law in the Nineteenth Century', 22 Journal of Legal History 45-71 (2001).
} 
voluntary were breached, with taxes that were not required directly to meet a national emergency and that were compulsory - notably the income tax - becoming accepted, albeit reluctantly, as a regular part of the tax system. It was necessary to do so to meet the increasing demands of the Exchequer. The requirements that a tax should be noninquisitorial and locally administered, though eroded, were more robust and enduring. The battle to retain them was fought in the context of the income tax until well into the twentieth century. As taxation came to affect a greater proportion of the public, so other, latent, concepts of fairness in tax were revealed. These perceptions of fairness, which had always existed alongside the orthodox canons but had been obscured by them, focussed to a greater extent on the taxpayer rather than the tax. Essentially they demanded not an examination of the fairness of the tax as such, in terms of the tax base for example, but rather the fairness of the position of the individual taxpayer in relation to his fellow taxpayers. They were based on whether taxation in general and individual taxes in particular ensured the equal treatment of taxpayers in two senses. The first was that one group within a tax should not pay more than another in proportion. ${ }^{18}$ This public understanding of fairness emerged strongly in the middle years of the nineteenth century, when it became understood that the income tax was practically if not theoretically permanent. The introduction of estate duty in $1894^{19}$ raised new challenges and also demanded a re-evaluation of the notions of fairness beyond those inherent in the orthodox canons.

The second of these two emerging notions of fairness based on equality forms the subject of this chapter. It was that the treatment of taxpayers within a taxable group should be consistent, and therefore predictable, with no extraordinary individual hardship. This concern was not new. But it became more acute as tax legislation increased in volume and complexity in the nineteenth century. It was a notion of fairness that had always been felt

\footnotetext{
18 See Alun G. Davies, Render Unto Caesar? (Elek Books, London, 1966), pp. 79-90.

${ }^{19}$ Finance Act 1894 (57 \& 58 Vict. c. 30).
} 
keenly by taxpayers as individuals. Other 'higher' fairness, though certainly having a material effect on anyone subject to tax when they were ignored, lacked the directness of the imposition, by law, of extraordinary hardship on an individual. Such hardship would emerge at the administration stage of a tax, namely at assessment and collection. That stage of the taxation process which was always the most sensitive and at which individuals first felt the real impact of a tax. It was this 'lowest' notion of fairness - the avoidance of extraordinary individual hardship - that ultimately gave rise to executive equity: a body of rules developed by the executive in order to ensure the enacted law operated justly and fairly.

\section{ACHIEVING FAIRNESS}

Once the fact of taxation was accepted in the late eighteenth and early nineteenth centuries, fairness in tax could take any of three meanings: adherence to the orthodox canons of taxation; the equalising of the burden of taxation on all taxpayers; and consistency of treatment of taxpayers to ensure no taxpayer should suffer extraordinary individual hardship through the imposition of tax. The first and second elements were achieved through the substance of the tax law.

The taxes of the late eighteenth and early nineteenth century adhered to at least some of the canons in their very nature as expressed in the legislation. Most of the new taxes of the period could be ascribed directly to the exigencies of war. The triple assessment of 1798 and William Pitt's income tax of 1799 were both unequivocally introduced to meet the financial demands of the war against France and were accordingly necessary. Similarly, in the eighteenth century the tax base was carefully chosen. Most taxes then were deliberately and ostentatiously imposed on luxuries which did not need to be purchased if the taxpayer wished to avoid the tax. These taxes, it was argued, were therefore voluntary. The assessed 
taxes were imposed on the keeping of servants and on the purchase of such commodities as horses, carriages, windows, wigs, clocks, silver, hair powder and so on. ${ }^{20}$ Necessities such as bread, soap and candles were carefully avoided. The raft of stamp duties introduced in the late eighteenth century was similarly voluntary in nature. Nearly all the assessed taxes were by their nature non-inquisitorial, in that they could be assessed by external viewing. When Henry Addington recast the income tax in 1803 , he took great pains to ensure that its structure avoided the accusation of inquisition. He introduced the schedular system of income taxation, which endured for some two hundred years. This ensured that no one administrator/official would ever know the entire income of any given taxpayer. Finally, the law placed the administration of the land tax, assessed taxes and income tax in the hands of local lay tribunals to ensure that, ostensibly, these imposts were not administered by central government.

In the same way, the equalising of the burden of taxation throughout the taxpaying sector of society was achieved through policy choices as to the form and balance of taxes and the design of particular taxes. Both policy choices were expressed in legislation. A survey of the tax code from the eighteenth century to the present day reveals that the British system moved from a system dominated by indirect taxation to a more balanced one comprising both direct and indirect taxation. Individual taxes were increasingly designed to achieve internal equality. So generally, regarding tax policy, fairness came to be considered in terms of 'horizontal equity'. According to this notion, people in similar circumstances should pay the same amount of tax. Fairness was also considered in terms of 'vertical equity', which demands that people in different circumstances should pay a different amount; specifically, it demands that wealthier individuals pay proportionately more tax than poorer ones. Horizontal equity, which was advocated by Adam Smith in the eighteenth century, was and

\footnotetext{
${ }^{20}$ For a history of these taxes see Stephen Dowell, A History of Taxation and Taxes in England, 4 vols. (Longmans, Green \& Co, London, 1884), vol. iv.
} 
remains uncontroversial. Vertical equity was less readily accepted. Graduation at the lower end of the income scale had always formed part of the income tax, but the new estate duty of 1894 included a clear and comprehensive principle of graduation, with a scale of rates of the tax depending on the value of the estate. ${ }^{21}$ In 1910, after more than fifty years of debate, the same principle of graduation was introduced into the income tax through the medium of super-tax. ${ }^{22}$ Throughout the formative era of British tax, therefore, the substantive statutory law of tax was cast broadly in accordance with prevailing notions of fairness.

The formal law of tax could not, however, ensure comprehensive fairness. It was not inherently unfair in that it did not purport to treat individuals within a defined group differently. But the very nature of tax legislation undermined the third expression of fairness: the consistent treatment of taxpayers within a taxable group with no extraordinary individual hardship. Tax legislation had already, by the late eighteenth century, developed a unique character which was largely due to its constitutional underpinning. The Bill of Rights 1689 provided that a tax could only be imposed with parliamentary authority, namely with the consent of the taxpayer through his representatives. ${ }^{23}$ That became the exclusive legal basis of the right to levy tax and the liability to pay. It followed from this cardinal rule not only that all taxes had to be imposed by statute, but also that an individual could only be taxed through clear explicit words in the legislation and never by implication. Legislators accordingly attempted expressly to provide for as many situations as it was possible to foresee, either through lengthy detailed provisions or through a very wide charging clause, in order to ensure that all the taxpayers the legislature had intended to catch were indeed brought within the statutory language. Inevitably, Parliament could not envisage every situation where tax might become payable as a result of a statutory provision. Or a wide provision might have unforeseen consequences, and so there would arise cases where

\footnotetext{
${ }^{21}$ Finance Act 1894 (57 \& 58 Vict. c. 30$)$.

22 Finance (1909-10) Act 1910 (10 Edw. VII c.8) s.66.

${ }^{23} 1$ Will. \& M. sess. 2 c. 2 s. 4 (1689).
} 
taxpayers fell within the letter of a taxing Act but not within its spirit. Indeed, legislators and judges admitted that taxing provisions often had 'monstrous'24 results which Parliament could never have intended..$^{25}$

The judges of the courts could not address this unfairness. The constitutional requirement of taxation only by clear words was reflected in the attitude of the judiciary to the interpretation of tax statutes. For the whole of the formative period of British tax, and beyond, in interpreting the tax legislation to establish its scope, the judges could not look for the intendment of a tax Act and had to adopt a strict literal approach to its interpretation. ${ }^{26}$ They could have recourse only to the words of the enactment giving them their literal and natural meaning to reveal the intention of Parliament. ${ }^{27}$ That meant that the judges could not be driven by considerations of practicality or equity, and so could not introduce any flexibility into the tax code. If a taxpayer came within the clear words of a legislative provision imposing a tax, he was liable even though common sense, or indeed common humanity, might suggest that the legislature had no intention of bringing such an individual in those particular circumstances into charge. These were usually cases at the fringes of the code. ${ }^{28}$ The consequences of a literal interpretation were ignored. The clear words of the statute could be neither enlarged nor restricted to include or exclude any special case, even where their strict application led to hardship, absurdity or revealed a clear anomaly. ${ }^{29}$ The judges were not 'to be led away by the equities of any case' 30 and, as Lopes LJ remarked in 1894, 'we have nothing to do with whether the law may press hardly in certain cases, what

\footnotetext{
${ }^{24}$ IRC v Bates [1968] AC 483 at 516 per Lord Upjohn.

${ }^{25} \mathrm{Ibid}$. at 504 per Lord Reid

${ }^{26}$ Partington v. AG (1869) LR 4 HL 100 at 122 per Lord Cairns.

27 See generally Vinelott J, 'Interpretation of Fiscal Statutes', 3 Statute Law Review 78 (1982); David W. Williams, 'Taxing Statutes are Taxing Statutes: The Interpretation of Revenue Legislation', 41 Modern Law Review 404 (1978).

${ }^{28} \mathrm{Sir}$ Alexander Johnston, The Inland Revenue (George Allen \& Unwin Ltd, London, 1965), p. 68.

29 See, for example, Farr v Price (1800) 1 East 55.

${ }^{30} R v$ Winstanley (1831) 1 C \& J 434 at 440 per Lord Wynford.
} 
we have to do is to administer the law as we find it'. ${ }^{31}$ The judicial view was most famously expressed by Rowlatt J in 1921 when he observed that 'there is no equity about a tax.' ${ }^{32}$ Only where the words were ambiguous and had several meanings could nineteenth-century judges legitimately avoid a patent absurdity. ${ }^{33}$ In tax legislation, therefore, neither the old common law doctrine of the equity of the statute, nor its modern form of purposive statutory interpretation, whereby a statute was recognized as comprising both its letter and its 'sense,' 34 had any role to play. Whereas judges could normally correct unacceptable legislative rigour or address unforeseen situations, and call on notions of justice and fairness to go beyond the words of a statute, the strictest and most intense formalism surrounded tax statutes: words were everything.

The nature of tax legislation led to further unfairness. As a result of its underlying constitutional requirements, tax statutes were traditionally among the most complex, and certainly the longest, known to English law. ${ }^{35}$ And in the nineteenth century they became progressively more detailed and extensive as legislative adjustments were regularly made to close loopholes identified in earlier enactments, the income tax being the prime example. A code of such intricacy and volume inevitably led later draftsmen to adopt short cuts which added to its complexity and incoherence. Incorporation by reference, whereby an Act provided that it was to be read along with a series of other statutes as far as they were consistent, was a common practice. The use of standard forms across the taxes was usual. Loose wording and lack of definition were equally typical features of tax legislation. These drafting practices resulted in provisions or combinations of provisions having unforeseen consequences. Loose drafting, in particular, led to ambiguous and uncertain provisions. This

\footnotetext{
${ }^{31}$ Grainger and Son v Gough (1894) 3 TC 311 at 321 per Lopes LJ. But see the slight modification of the strictness of the rule in Colquhoun $v$ Brooks (1889) 2 TC 490.

${ }^{32}$ Cape Brandy Syndicate $v$ IRC [1921] 1 KB 64 at 71.

${ }^{33}$ A G v Hallett (1857) $2 \mathrm{H} \& \mathrm{~N} 368$ at 375 per Pollock CB.

${ }^{34}$ See J.D. Heydon, 'Equity and Statute' pp. 42-47.

${ }^{35}$ G. S. A. Wheatcroft, 'The Present State of the Tax Statute Law', (1968) British Tax Review 377-393; John Clark, 'Statutory Drafting', (1980) British Tax Review 326-340.
} 
resulted in individuals or groups of individuals being brought into charge when, again, it appeared absurd or unjust to do so.

Instances of such unfairness are found throughout the tax regime of the nineteenth century. The legislative framework struggled to keep up with the astonishing pace of social and economic change which characterised that period in Britain's history. Nineteenth century tax legislation, almost without exception, was antiquated, inconsistent, illogical, incoherent, complex and obscure. Stamp duties, excise duties, the land tax, assessed taxes and even the income tax were all essentially of an eighteenth century character in their underlying structures and processes, and they suffered the deficiencies of all tax legislation.

Since it was the nature of tax legislation which gave rise to unfairness and individual hardship, the taxes that best reveal revenue practices specifically conceived to ensure fairness are those older taxes which remained unreformed during the dynamic tax developments which marked the nineteenth century. These were relatively few. Most of the taxes introduced in the eighteenth century were at least partially reformed during the nineteenth, but a striking example of a tax that was left virtually untouched in terms of reforming legislation was the medicine stamp duty. As a result, it was rife with antiquated and anomalous provisions; it reflected a lack of the fiscal sophistication that was to characterise later taxes; and it suffered the problems of being based on a species of tax itself already a century old and initially conceived with a very different tax base. This gave rise to widespread injustices and hardships on an individual basis, and as a result the tax became one dominated by revenue practice to an extraordinary degree.

As such, the medicine stamp duty provides a revealing model for the examination of the executive equity which pervaded the whole tax system. This was one of many stamp duties on commodities - in this case, proprietary medicines - introduced to raise money in a 
time of severe financial exigencies in 1783.36 Being of minor fiscal importance, it was left almost entirely unreformed for the whole of its 160 year history. This, and the complexity of the statutory provisions, which resulted from the considerable challenges of definition in this field of activity, gave rise to unacceptable hardship or injustice where the legislation was to be strictly applied. The spirit of the legislation was to impose a duty at the point of sale on what were popularly called quack medicines, which were sold by unqualified and unscrupulous individuals to the detriment of the public good. However, the comprehensive letter of the legislation caught many products which were not medicines at all in the usual sense of the term, as well as some products which were regular medicines sold by qualified and responsible practitioners. The legislation also caused individual injustice and hardship among the body of sellers of proprietary medicines at which the Act was undeniably directed, with some individuals being liable, others not, for no apparently sound principle. The medicine stamp duty constitutes an extreme example of a tax which, applied strictly in accordance with constitutional norms, gave rise to widespread unfairness to the public and to the pharmaceutical profession.

\section{The PRACTICE Of THE EXECUTIVE}

The British constitution thus required any charge to tax to be imposed predictably, rigorously, and by explicit legislative provision; no element of the taxing provision was to be left to implication. Flexibility, discretion, justice, intendment, conscience, equality: all these qualities that reflected the essential and original ethos of legal equity were the antithesis of the requirements of tax law. With their pragmatic appreciation that taxation is consensual and that compliance is crucial to the success of any tax, the revenue authorities understood

\footnotetext{
3623 Geo III c. 62. The tax was revised two years later to adopt its modern form (25 Geo III c. 79) and re-enacted in 1812 (52 Geo III c. 150). The 1812 Act remained in force and almost entirely unreformed until the abolition of the tax in 1941.
} 
that individual instances of unfairness had to be addressed as a matter of urgency in order to ensure the tax in question was acceptable to the wider public. The amendment of the substantive law by parliamentary process to address unfairness at the margins of the legislative code was then, as now, impracticable where perhaps only a very few taxpayers were affected or the difficulty in expressing the case of unfairness insuperable. And with the judiciary constrained primarily by constitutional imperatives, the only way that the unfairness caused by the special nature of tax legislation could be cured was through the modification of its practical implementation. This matter was the responsibility of the revenue departments of the executive. These were the organs of central government charged with the administration of the different taxes. In the nineteenth century, they consisted of the various boards: ${ }^{37}$ the boards of excise, customs, stamps and taxes. The various boards existed separately, at first, and subsequently underwent a variety of mergers culminating in 1849 in the creation of the Board of Inland Revenue, which held charge of the excise, stamps and taxes for the rest of the nineteenth century. ${ }^{38}$ During this period, the fiscal demands of central government grew in the new economic conditions of industrial and commercial transformation. As this was reflected in taxation of increasing scope and sophistication, so the revenue authorities themselves became amongst the most powerful and influential of government departments, a development aided by their striking degree of independence and autonomy. ${ }^{39}$ Fairness or equity in tax was thus achieved neither through parliament nor the courts. It was achieved in large measure by the revenue authorities of the executive who took it upon themselves to mitigate the strictness of the legislation where it worked

\footnotetext{
${ }^{37}$ See generally, Sir John Craig, A History of Red Tape (Macdonald \& Evans Ltd, London, 1955), Chapter 9.

3812 \& 13 Vict. c. 1; See generally Wyn Griffith, A Hundred Years, The Board of Inland Revenue 1849-1949 (Inland Revenue, London, 1949), pp. 2-6. The excise was removed from the Board of Inland Revenue in 1909 and transferred to a Board of Customs and Excise.

39 The members of the boards were appointed by the Crown: Sir Alexander Johnston, The Inland Revenue (George Allen \& Unwin Ltd, London, 1965), p. 21. See the Twentieth Report of the Commissioners of Inquiry (Excise Establishment), HCPP (1836) (22) xxvi 179 at p. 303.
} 
unacceptable hardship. Only they could 'temper the wind to the shorn lamb.' 40 So just as the judges in the regular courts recognised the need to give expression to the equity of statutes in other spheres and did so by conceiving the intention of the legislature, so the revenue authorities of central government stepped in to fill the judicial lacunae in tax legislation. When these officers of the executive intervened to modify the law, they drew on the equitable tradition, making their decisions on the basis of fairness, ${ }^{41}$ as the term was conceived in relation to tax.

The principal means whereby the revenue authorities introduced a measure of flexibility into the tax code, in the interests of fairness, was where they ignored a statutory provision entirely or applied a beneficial administrative interpretation (or re-interpretation) of a clear statutory provision whose ordinary meaning would have brought the individual into the charge to tax. These were not instances of ambiguous or uncertain provisions. They were cases where an individual was clearly within the meaning of the statutory provision and accordingly liable to tax, or else excluded from a provision of tax relief, but where the revenue authorities took the view that to apply the law - either strictly or indeed at all would cause unacceptable hardship. In such cases tax was legally payable, but the revenue authorities took it upon themselves to waive the payment.

The medicine stamp duty provides many examples. For instance, certain 'medicines' were undoubtedly within the charge to tax when sold, the statute clearly saying so. And yet the revenue authorities refused to tax them because to do so would be unfair. It was thus revenue practice not to products which in their view were not medicines at all. The authorities accordingly allowed peppermint and ginger lozenges, which were widely

\footnotetext{
${ }^{40}$ Michael Nolan, 'The Unsatisfactory State of Current Tax Law,' (1981) Statute Law Review 148-52 at p. 150. On the exercise of discretion in revenue administration, see David W. Williams, A Mere Matter of Machinery (Unpublished LL.M thesis, University of Wales 1975), pp. 54-97. The shepherding impulse to temper the wind to the shorn lamb may be seen at work in cases of 'legal equity': e.g. Pennington $v$ Waine [2002] EWCA Civ 227, [2002] 1 WLR 2075, [54], [59].

${ }^{41}$ A movement seen more generally in the developing administrative state: see Henry E. Smith, 'Equity and Administrative Behaviour.'
} 
consumed in the nineteenth century and were undoubtedly within the letter of the legislation, to be sold free of duty. The authorities' view was that the lozenges were confectionary and not medicines, and so not within the spirit of the legislation. ${ }^{42}$ Other articles whose sale was strictly within the charge, but to which the same revenue practice was applied, were the toiletries sold by hairdressers and perfumers. ${ }^{43}$ Similarly, some perfumes and preparations, such as Eau de Cologne and Arquebusade Water, were expressly within the charge to tax. However, the revenue authorities decided not to tax them because, where customs duty had already been paid on perfumed spirits, it would have been unfair to tax them a second time. And again, the revenue authorities were mindful of the injustice of double taxation when they waived the payment of the medicine stamp duty on some beverages containing medicinal drugs, such as dandelion coffee, if the excise duty on coffee substitutes was also payable. ${ }^{44}$ Another concession of the revenue authorities was to permit the breaking up of bulk packages of medicines (on which the duty had already been paid) and the selling of the contents in penny twists of paper. Although they could have insisted on the payment of the tax on the sale of the penny twists, they did not do so on two grounds: (i) that it would be unjust for the tax to be paid twice, and (ii) that, as the duty strictly payable on the penny twists would be more than double the price of the medicine, to insist on the further tax would be to treat poorer customers unfairly. Revenue practice in this tax also shows that commercial fairness was equally valued. The authorities introduced a concession for foreign medicines, which were subject to the medicine stamp duty, when they were sold by a British wholesaler to a retail chemist for the purpose of making up

\footnotetext{
42 William Chamberlaine, History of the Proceedings of the Committee appointed by the General Meeting of Apothecaries, Chemists, and Druggists, in London, for the Purpose of obtaining Relief from the Hardships imposed on the dealers in Medicine, by certain Clauses and Provisions contained in the new Medicine Act, passed June 3, 1802, etc (London, 1804), pp. 31-32. Lozenges were eventually removed from the charge by 55 Geo III c.184 s.154 (1815).

438 Pharmaceutical Journal 155 (1848-49) (1 $1^{\text {st }}$ series).

${ }^{44}$ Board of Customs and Excise and Predecessor: Private Office Papers, The Medicine Stamp Duties 1783-1936, The National Archives [hereafter TNA] CUST 118/366 at p. 37.
} 
prescriptions. The revenue authorities would not press for the tax in such cases, the reason for this so-called 'dispensing concession' being to put British manufacturers on the same commercial footing as foreign manufacturers. ${ }^{45}$ Similarly, the Board felt it was unjust to deny the 'known, admitted and approved remedies' exemption to limited companies where a qualified chemist was employed, though the legislation forbade it. ${ }^{46}$

The medicine stamp duty was an extreme example, but newer and quite different taxes equally needed their hard effects to be mitigated by the revenue authorities. For example, the authorities moderated the inequitable effect of a provision in the Succession Duty Act 1853 whereby the rate of tax was determined according to the chronology of succession rather than merit. ${ }^{47}$ Succession duty provided another important instance of remission after the death in 1894 of Alexander III, the Emperor of Russia, though not a case of individual hardship in the conventional sense. ${ }^{48}$ The revenue authorities, though reluctant at first, ultimately waived their right to collect death duties on certain bonds the Emperor held in the Bank of England. There was no doubt that the property was legally liable. But on the grounds of 'international comity,' namely the treating of 'the foreigner and native as entitled to a like measure of justice,'49 special privileges were accorded to the Emperor's estate and payment of the tax was not pressed for..$^{50}$ There was some precedent for this, as there had developed a practice of permitting the remission of certain customs duties for foreign ambassadors. ${ }^{51}$

\footnotetext{
45 Ibid. at pp.67-8; E. N. Alpe, Handy Book of Medicine Stamp Duty (London, 1888), p. 110.

${ }^{46}$ Ibid., pp. 83, 89-90.

${ }^{47}$ Succession Duty Act 1853 (16 \& 17 Vict. c. 51) s. 11; Second Report of the Commissioners of Inland Revenue, HCPP (1857-8) (2387) xxv 477 at pp. 502-3.

48 John Booth, The Inland Revenue...Saint or Sinner? (Coracle Publishing, Lymington, 2002), pp. 167175 .

49 Second Report and Minutes of Evidence before Committee of Public Accounts, HCPP (1897) (196) viii 5, q. 420.

50 Ibid. p. vi; qq. 358-432.

${ }^{51} \mathrm{Ibid}$. qq. 423-6.
} 
These specific examples were just a few of dozens of remissions granted by the revenue authorities on the grounds of undue hardship throughout the nineteenth century across the tax regime. The remissions continued in force into the twentieth century, and increased in number. ${ }^{2}$ At the same time, their purpose came more often to be expressly articulated. The remissions were designed to achieve fairness in the tax system by 'softening the rigour of the law'53 - an invocation of Lord Ellesmere's famous pronouncement on legal equity, if ever there was one ${ }^{54}$ - to work 'great justice between the Crown and the subject'.55 They constituted 'an act of administrative mercy,'56 'a discretionary forbearance', 57 'a relaxation ... to deal with what are, on the whole, minor or transitory anomalies under the legislation and to meet cases of hardship at the margins of the code where a statutory remedy would be difficult to devise or would run to a length out of proportion to the intrinsic importance of the matter.'58

In short, the many remissions developed and maintained to ensure that the tax legislation operated fairly, and the historical evidence supports the view that they succeeded in doing so.

Remissions, or extra-statutory concessions, as they came to be known, were not the only instance where the revenue authorities made discretionary decisions on the grounds of fairness. They did likewise where they assigned a 'fair' meaning to a provision in the tax legislation. Where a provision was uncertain or ambiguous, the task of assigning a meaning to it inevitably fell on the executive. ${ }^{59}$ So numerous were such provisions that a

\footnotetext{
52 See generally Sir Alexander Johnston, The Inland Revenue (George Allen \& Unwin, London, 1965), pp. 67-8; David W. Williams, 'Extra Statutory Concessions' (1979) British Tax Review 37-144.

${ }_{53}$ H.W.R. Wade, Constitutional Fundamentals (Stevens \& Sons, London, 1980), p. 57.

${ }^{54}$ The Earl of Oxford's Case ***; and see D Ibbetson, 'The Earl of Oxford's Case' in C Mitchell and P Mitchell (eds.), Landmark Cases in Equity (Hart, Oxford, ${ }^{* * *}$ ) [editor to supply refs]

${ }_{55}^{5}$ Korner v IRC [1969] 1 WLR 554 at 558 per Lord Upjohn.

${ }^{56}$ H.W.R. Wade, Constitutional Fundamentals (Stevens \& Sons, London, 1980), p. 57.

578 Pharmaceutical Journal 212 (1848-49) (1 ${ }^{\text {st }}$ series)

58 http:/ / www.hmrc.gov.uk/specialist/esc.pdf

${ }^{59}$ See Sir Maurice Sheldon Amos, 'The Interpretation of Statutes', 5 Cambridge Law Journal 163 (1934).
} 
great deal of the time of revenue officials was spent on this task. In most cases they had to do so simply to ensure the provision could be implemented at all. But in some instances the evidence reveals that the authorities actively preferred an interpretation because it would be perceived as fair and did not catch those cases on the fringe that it had never been intended to catch. Yet again, the medicine stamp duty provides clear examples. The tax applied to products which relieved 'ailments'. The authorities regarded it as unfair to include within this term conditions such as baldness, dandruff, freckles or chapped lips because to treat these conditions as ailments would catch too many products which came outside the spirit of the Act. 60 The charge applied only to 'preparations', which term the revenue authorities interpreted restrictively to require some element of active processing. For example, unprepared herbs were thus allowed to escape the charge. ${ }^{61}$ The charge also applied to articles that were 'recommended,' an immensely broad term encompassing advertisement and dosage instructions. Through the interpretation of this broad term, the revenue authorities were able to include or exclude medicines as they saw fit. Such examples are found in their hundreds and pervade the entire tax code: from the Excise Board interpreting the provision imposing a tax on every horse running for any kind of prize 'in its spirit rather than in its letter' so as to exempt all hunters and horses running for farmers' and yeomanry plates, ${ }^{62}$ to a liberal interpretation of the income tax provisions for computing trading profits so as to permit deduction for wear and tear of machinery and plant. ${ }^{63}$ By the practical expedients of granting remissions and applying beneficial administrative interpretations and re-interpretation to statutory provisions of uncertain meaning, the revenue authorities

\footnotetext{
${ }^{60}$ Board of Customs and Excise and Predecessor: Private Office Papers, The Medicine Stamp Duties 1783-1936, TNA CUST 118/366 at p. 48.

61 TNA IR 83/61.

${ }^{62}$ Thirteenth Report of the Commissioners of Inland Revenue, HCPP (1870) (C. 82, 82-1) xx 193 at p. 255.

${ }^{63}$ Twentieth Report of the Commissioners of Inland Revenue HCPP (1878) (C. 1896) xxvi 593 at 64648; Twenty-first Report of the Commissioners of Inland Revenue, HCPP (1878) (C. 2158) xxvi 717 at 780; Appendix to the Departmental Committee on Income Tax, HCPP (1905) (Cd. 2576) xliv 245 at pp. 258-9.
} 
ensured that the complex, antiquated and rigid legislative framework of the tax code operated as fairly as possible.

\section{EXECUTIVE EQUITY}

Revenue practice, including executive equity, rapidly became a permanent feature of the tax system of immense importance. As early as the eighteenth century, it was universally recognised that an understanding of tax law was incomplete - indeed impossible - without a familiarity with tax practice. Though supplementary in nature, and engrafted upon the formal statutory code, it was perceived as an integral part of tax law, much as the settled doctrines of 'legal equity' came to be integral within the English legal system. Commentaries of all kinds, popular and expert, on taxation matters rarely drew any distinction between the statutory provisions and the revenue practices adopted in their implementation. Indeed, it was sometimes difficult to tell in the nineteenth century what was law and what was practice. The inference was that revenue practice was nothing less than quasi-law in terms of substance and authority. ${ }^{64}$ A number of factors were responsible for this growing status.

Because revenue practices were caused primarily by the nature of nineteenth century tax legislation, they were copious. They began to develop from the moment a tax statute was enacted and, although, as far as it can be judged, practices that developed purely to ensure fairness formed only a small proportion of the whole, a huge body of revenue practice addressed the daily implementation of tax law for the purely practical end of effective implementation. Revenue practice was based on unsurpassed technical expertise and the authority of experience. Indeed, for most of the nineteenth century, until the emergence of a small tax bar, tax officials were the only experts in the field. Although many members of the

\footnotetext{
${ }^{64}$ R.E. Megarry famously described extra-statutory concessions, and indeed practice notes, as prime examples of 'quasi-legislation': R.E. Megarry 'Administrative Quasi-legislation' 60 Law Quarterly Review 125-129 (1944).
} 
revenue boards were appointed from other areas of public life, a proportion rose through the revenue service where over the years as revenue officers they had acquired, through competitive examination and special training, a profound and minute knowledge of tax law and an unrivalled experience in the practice of the revenue. ${ }^{65}$ And all the boards and their officers had the support of their own specialist legal staff.66 Not only did this expert knowledge give their numerous pronouncements authority; it gave the development of a body of quasi-law a measure of inevitability and momentum and promoted the development of an executive jurisprudence.

The revenue authorities undoubtedly intended their interpretations, remissions and decisions to be acted upon and rigorously adhered to by their officers, and they achieved this. From the eighteenth century onwards, the decisions were included in the circulars, regulations, orders and instructions that the central boards in London constantly disseminated to their officers all over the country. ${ }^{67}$ These instructions as to how the taxes were to be administered were conclusive as far as the officers of the boards were concerned. The officers had to follow the central boards' instructions and implement them to the letter; indeed, to the same degree as Acts of Parliament and judicial decisions. ${ }^{68}$ After all, the officers were subject to very close and rigorous control by the revenue boards. As a result, revenue practice had immense de facto legal force. As far as taxpayers were concerned, it was binding on them, and would remain so until it was declared illegal by the judges of the regular courts. It was a courageous and wealthy individual indeed who would challenge the revenue boards' interpretations of the law in the courts. This, and restricted rights of appeal in many tax matters, made any judicial engagement with tax law rare in the nineteenth

\footnotetext{
${ }^{65}$ For the recruitment and training of surveyors, see David Williams, 'Masters of All they Surveyed: 1900-1914', (2005) British Tax Review 142 at 144-7.

66 See Minutes of Evidence before the Select Committee on Inland Revenue and Customs Establishments, HCPP (1862) (370) xii 131, q. 2200.

${ }^{67}$ See for example, Precedents and Instructions, TNA IR 78/289 (1903); TNA IR 78/60.

${ }^{68}$ Instructions to Surveyors on that part of their Duty which relates to Taxes (HMSO, London, 1855), p. 5; 12 \& 13 Vict. c. 1 s. 3 (1849); David Williams, 'Surveying Taxes', (2005) British Tax Review 222.
} 
century. It resulted in the revenue boards' enjoying a monopoly on the initial interpretation of tax legislation and ensured the relative endurance of their decisions.

Remissions and interpretations made on the grounds of fairness were taken on the basis of each individual case; a record of systematic practice in awarding remissions and offering beneficial administrative interpretations (and re-interpretations) of revenue statutes is absent. Nevertheless, there is clear evidence that not only was there a widespread reluctance to disturb established practices on the grounds of efficiency, ${ }^{69}$ but also that they had the force of precedent within the service. This was so even where a practice was subsequently found to be unsound. A famous exemption to the medicine stamp duty, for example, was that for 'known, admitted and approved remedies' sold by a qualified person. ${ }^{70}$ Having in practice disregarded this statutory provision for the whole of the nineteenth century as being merely declaratory in nature, ${ }^{71}$ the revenue authorities were forced to recognise its legal force as a result of a judicial decision in 1903 to the effect that it was a material exemption. ${ }^{72}$ Motivated by pragmatic imperatives rather than any ideals of fairness, the revenue authorities interpreted this decision in an extraordinary way, effectively disregarding it and giving the exemption such a wide scope that it could be claimed by any chemist disclosing the formula of his medicine. ${ }^{73}$ Bearing so little relation to the letter of the statute, this concession was undoubtedly flawed, and the revenue authorities later admitted that it had continued only because there was an institutional

\footnotetext{
${ }^{69}$ See for example the reluctance in 1905 to disturb the basis of assessment for Schedule D on the grounds that it 'will cause such a disturbance in the Income Tax practice which has grown up during the sixty years the tax has been in existence...': Appendix to the Report of the Departmental Committee on Income Tax, HCPP (1905) (Cd. 2576) xliv 245 at p. 268.

7052 Geo III c. 150 (1812).

${ }^{71}$ Minutes of Evidence before the Select Committee on Patent Medicines, HCPP (1914) (Cd. 414) ix 1, q. 19; Board of Customs and Excise and Predecessor: Private Office Papers, The Medicine Stamp Duties 1783-1936, TNA CUST 118/366 at p. 56.

${ }^{72}$ Farmer $v$ Glyn Jones [1903] 2 KB 6.

73 TNA IR 83/61; Board of Customs and Excise and Predecessor: Private Office Papers, The Medicine Stamp Duties 1783-1936, TNA CUST 118/366 at pp. 84-6; Minutes of Evidence before the Select Committee on Patent Medicines, HCPP (1914) (Cd. 414) ix 1, qq. 19-34.
} 
reluctance to disturb the clear interpretation of the Board of Inland Revenue. ${ }^{74}$ Furthermore, when in the last years of the nineteenth century some of the practices became more formalised - notably the reporting to the Public Accounts Committee ${ }^{75}$ of those remissions granted to individuals 'from motives of equity or of compassion' - the status of revenue practice as a body of quasi-law, 'a kind of code,'77 was reinforced.

Supporting these factors was the popular approval that revenue practice enjoyed. It was developed with the best of motives. Other than in the deliberate undermining of the principle of localism in tax administration, ${ }^{78}$ the intention of the revenue authorities in developing their body of practice was not to ensure control over the taxing process. Although it was early understood that the revenue authorities could go beyond the intention of parliament and favour the state rather than the taxpayer in their zeal to raise the public revenue ${ }^{79}$ for most of the nineteenth century the popular consensus was that the authorities were not sinister in their development of their executive equity. While it may have been a symptom of the growing power of central government, it was not a deliberate encroachment thereof, or 'officialism' as it was popularly known. On the contrary, the revenue authorities were simply trying to ensure the tax system was fair in those specific instances. Admittedly this was ultimately in the interests of compliance, but it was not in order to increase the authorities' control over the system. Indeed, the evidence confirms they would rather not have had to make these concessions and interpretations to ensure fairness, and that they recognized it as unsatisfactory to implement a tax on that basis. They wanted, above all, a

\footnotetext{
${ }^{74}$ Board of Customs and Excise and Predecessor: Private Office Papers, The Medicine Stamp Duties 1783-1936, TNA CUST 118/366 at p. 88.

${ }^{75}$ First Report from the Select Committee of Public Accounts, HCPP (1928) (Cmd. 35) v 1 at p. 8; Second Report from the Committee of Public Accounts, HCPP (1897) (C. 196) viii 5 at p. 11.

${ }^{77}$ H.W.R. Wade, Constitutional Fundamentals (Stevens \& Sons, London, 1980), p. 58.

78 C. Stebbings, The Victorian Taxpayer and the Law (Cambridge University Press, 2009), pp. 77-110, especially pp. 103-105.

${ }^{79}$ See H. H. Monroe, 'The Constitution in Danger', (1969) British Tax Review 24 at 30.
} 
sound legislative regime to apply. ${ }^{80}$ In its absence they did what they could to ensure fairness. The system they developed was pragmatic, flexible, and provided substantial and procedural justice. And from the end of the nineteenth century, despite some concerns as to the extent of revenue practice in extreme cases such as the medicine stamp duty, ${ }^{81}$ the revenue authorities were consistently praised for their 'extreme fairness and courtesy' in dealing with borderline cases 82 and for their common sense in making decisions in order to make the tax system work. 83

It might be thought that the development of an executive equity, aimed at ensuring that the injustices which inevitably flowed from such a complex and technical legislative system of tax law were remedied, was as beneficial to the taxpayer as the development of 'legal equity' had been to ensure justice for the population subject to the common law. The growing authority of revenue practice, however, hid serious flaws. While arguably it ensured fairness for the individual directly subject to the decision, in terms of the wider body of taxpayers it introduced a greater and more widespread degree of unfairness. Unlike legal equity, executive equity in tax was unable to balance out the needs of certainty against individual fairness. Indeed, it undermined the classical canon which laid down that the instances where a subject was to be charged to tax should be, in the words of Lord Ellenborough CJ in 1807, 'fairly marked out.' ${ }^{84}$ It has been seen that revenue practice bound a taxpayer de facto; for 'rule of law' reasons, it followed that taxpayers should be able to access it in order to find out with some degree of certainty the nature of the charge to tax, and whether it applied to their own personal situation or not.

\footnotetext{
80 See for example 10 Pharmaceutical Journal 625 (1868-69) (2nd series).

81 See for example 6 Pharmaceutical Journal 780 (1875-6) (3rd series); 19 Pharmaceutical Journal 682 (188889) (3 $3^{\text {rd }}$ series).

82 Minutes of Evidence before the Select Committee on Medicine Stamp Duties, HСPP 1936-37 (Cmd. 54) viii 129 at p. 220.

${ }^{83}$ Report of the Income Tax Codification Committee, HCPP (1935-6) (Cmd. 5131) xii 1 at pp. 15-16.

84 Warrington v Furbor (1807) 8 East 242 at 245.
} 
It was, however, almost impossible for a taxpayer to acquire any certainty, predictability or understanding of his fiscal position because revenue practice was utterly inaccessible. Physical and intellectual inaccessibility already permeated tax law, from an incomplete, piecemeal and uncodified constitution to vast and impenetrable formal statutory provisions and unrecorded tribunal decisions. Revenue practice made a serious situation intolerable. Although most revenue practices were recorded, it was not in any systematic way. They were scattered throughout the voluminous literature on the taxes, and found recorded in internal circulars and instructions published for the use of revenue officials; referred to in evidence given to Select Committees and Royal Commissions, sometimes in the formal minutes of the proceedings of the revenue boards; and articulated in correspondence between the revenue boards and their officers, the Treasury or taxpayers. Some remissions, such as the dispensing concession granted to pharmaceutical chemists under the medicine stamp duty, were not formally recorded at all. Even where there was some record, it was almost impossible for a taxpayer or his legal advisers ${ }^{85}$ to access revenue practice other than with the willing cooperation of the revenue authorities. The official view was one of secrecy. The minutes, instructions and circulars which revealed the policies and practices of the central boards were regarded as strictly confidential. They were never made public for fear that they might bind the boards or be pleaded in litigation against them ${ }^{86}$ or, equally, that they would be 'equivalent to an admission that they neglect their duty by not enforcing the law to the strict letter.' ${ }^{87}$ The board of excise was an extreme example. While it published its thousands of general orders in one volume in 1829,88 it consistently refused to

\footnotetext{
${ }^{85}$ Report of a Committee on Excise Establishment, HCPP (1837) (96) xxx 397 at p. 595.

86 Twentieth Report of the Commissioners of Inquiry (Excise Establishment), HCPP 1836 (22) xxvi 179 at p. 525. For the extent to which the revenue authorities are today bound by their informal decisions, see Daniel Sadler 'The Revenue Giveth - the Revenue Taketh Away' 53 Cambridge Law Journal (1994) 273-281.

878 Pharmaceutical Journal 213 (1848-49) (1 1 st series).

88 John Owens, Plain Papers relating to the Excise Branch of the Inland Revenue Department (Linlithgow, 1879), p. 261.
} 
allow them to be seen by the traders subject to the excise, or to publish any guidance based on them. ${ }^{89}$ It would not even allow a printed analysis of the excise laws to be made available outside the service. ${ }^{90}$ And when the revenue authorities published explanatory pamphlets in relation to the different taxes, these tended to consist of a statement of the legislative provisions, a measure of clarification, and only occasionally an explanation of their practice. ${ }^{91}$

Public discussion and reporting of revenue practices was very limited. While the annual reports of the revenue boards sometimes discussed them, it was pure chance whether a taxpayer's particular situation would be mentioned, and as the century progressed, so the reports became increasingly brief and formulaic. Select Committees or Royal Commissions on taxation issues occasionally addressed revenue practice. The evidence and reports of these official inquiries were published and thereby made accessible to the public, at a price. With tens of thousands of questions in the minutes of evidence alone being commonplace, and some tax knowledge being necessary to identify the relevant subject matter and navigate the material, they were entirely impracticable for any taxpayer who sought to inform himself as to his own tax position.

The only secure way by which taxpayers could find out the practice applicable to their own fiscal situation was to ask the revenue authorities themselves. The public well understood that the revenue officers were the true experts in the complex and technical law of tax, and that only they would have any accurate knowledge of the practices and policies of the board. At a time when there was no tax profession and self-help associations were in their infancy, individuals necessarily relied on the advice of the officers of the revenue

\footnotetext{
89 Twentieth Report of the Commissioners of Inquiry (Excise Establishment), HCPP 1836 (22) xxvi 179 at p. 525.

${ }^{90}$ Fourteenth Report of the Commissioners of Inquiry into the Excise Establishment (Paper), HCPP 1835 (16) xxxi 159 at pp. 181-2.

${ }^{91}$ For the Instructions to Officers relating to the Medicine Stamp Duty, see 8 Pharmaceutical Journal 153-162 (1848-49) (1 ${ }^{\text {st }}$ series); 82 The Pharmaceutical Journal 674-676 (1909).
} 
boards, from the local surveyors ${ }^{92}$ to the members of the boards themselves. The evidence shows that the boards differed as to their approachability. For example, the Board of Inland Revenue was widely appreciated as an accessible and helpful board, 93 which willingly answered the queries of individual taxpayers as to their own personal assessments. In contrast, the Board of Excise was deliberately obscure and secretive, reluctant to respond to inquiries or disclose its practice. ${ }^{44}$ Where the taxpayer was a member of a professional organisation, he could find out about revenue practice by that route. For example, the editors of the Pharmaceutical Journal, the official organ of the Pharmaceutical Society of Great Britain, not only printed their correspondence with the revenue authorities, but also the board's instructions to its own officers in which the law and the manner of its interpretation were set out. ${ }^{95}$ But however accessible and helpful the revenue authorities were, it is clear that they entirely controlled the nature and volume of information as to their practice that was released to the public. Their position as the only authoritative source of this key element of tax administration served to reinforce the view that the tax legislation meant what the revenue authorities said it meant. Taxpayers had little choice but to accept it.

Certainty in tax affairs was further undermined because, as with any body of truly discretionary decisions, revenue practice lacked any obvious coherence. The practices that the revenue authorities developed to ensure fairness were occasional ad hoc decisions made in the course of the administration of tax to relieve hardship in extreme cases. Even when the practices were referred to in the formal day-to-day minutes of the boards' proceedings,

\footnotetext{
92 David Williams, 'Surveying Taxes, 1900-14', (2005) British Tax Review 222 at 229.

${ }^{93}$ Minutes of Evidence before the Select Committee on Inland Revenue and Customs Establishments, HCPP (1862) (370) xii 131, q. 504; Twentieth Report of the Commissioners of Inland Revenue, HCPP (1878) (C. 1896) xxvi 593 at p. 646. Occasionally the surveyor gave general advice through the medium of the local newspaper, as when in 1843 the Exeter surveyor published a letter in which he carefully explained the nature of income tax appeal proceedings: see Trewman's Exeter Flying Post, 12 January and 19 January 1843. For the response of the board to chemists' inquiries, see for example 9 Pharmaceutical Journal 544 (1878-9) (3rd series).

${ }^{94}$ Fourteenth Report of the Commissioners of Inquiry into the Excise Establishment (Paper), HCPP (1835) (16) xxxi 159 at p. 182. See too ibid p. 285.

${ }^{5} 14$ Pharmaceutical Journal 147 (1854-55) (1 ${ }^{\text {st }}$ series)
} 
the record was purely factual. Very rarely was the reasoning behind a decision explained. An allusion in the minutes to internal correspondence explaining the decision was usually the most that was found. As a result, revenue practices were almost invariably unexplained, with the unfairness they were purporting to address being implicit rather than explicit. A general trend of the executive trying to achieve fairness emerges, but the instances are haphazard and founded entirely on the merits of the individual case. Furthermore, any fairness which practice was intended to introduce was that decided upon by the revenue authorities. The judges of whether the treatment of an individual subjected to the letter of the tax code was unduly harsh were the commissioners of the board in question. They arrived at their decisions on the basis of their own experience, their understanding of the intention behind the legislation, the reports of their officials and the advice of their legal staff. The point was emphasised in the following century when a judge observed that the revenue authorities had 'worked out what they consider to be an equitable way of operating [the statutory provision in question] which seems to them to result in a fair system of taxation.' 96 The board's conception of fairness was not necessarily that perceived by the general taxpaying public. The bureaucratic view of fairness was inevitably tempered by practicality and encompassed the desire for efficiency and uniformity in tax administration considerations the general public's view of fairness did not necessarily include.

To that extent, then, fairness was determined not by the length of the Chancellor's foot but that of the chairman of the board. The interpretation of the 'known, admitted and approved remedies' exemption in the medicine stamp duty, for example, was the personal view of Sir Henry Primrose, the chairman of the board of inland revenue in 1904.97 This inaccessibility, and an uncertain provenance arising from a medley of pragmatic imperatives

\footnotetext{
${ }^{96}$ IRC v Bates [1968] AC 483 at 516.

${ }^{97}$ Board of Customs and Excise and Predecessor: Private Office Papers, The Medicine Stamp Duties 1783-1936, TNA CUST 118/366 at p. 88.
} 
and equitable objectives, made revenue practice appear both random and irrational to the taxpaying public. They could find no predictability, no consistency, and therefore no certainty in their relationship with the law of tax. One chemist observed in 1889 that 'the judgments of the Board of Inland Revenue as to liability to medicine stamp duty were uncertain and contradictory' and that the authorities seemed to be 'guided in their interpretation by expediency rather than principle.' 98 Unable conclusively and easily to tell whether a medicine was dutiable or not, revenue practice caused 'a sense of insecurity' among chemists. ${ }^{99}$

\section{CONCLUSION}

By the end of the nineteenth century the only way to ensure fairness at the margins of the formal tax code was by executive equity. It had evolved into a body of quasi-law, a significant and, for all practical purposes, a binding set of increasingly formal rules and guidance supplementing the formal law administered by an organ of the executive. It had become ingrained in the tax system in the crucial years of its development into a modern system as a gloss of complementary rules in response to an unacceptable though inevitable degree of formality, rigidity and complexity in the principal code of law with the objective of ensuring fairness between taxpayers. Despite its serious weakness of physical and intellectual inaccessibility - a practical problem of the interface of administration and law, - it was largely accepted by the taxpaying public, the legislature and the revenue authorities, all of whom recognized that it was both necessary and effective. Any discomfort as to the legality of revenue practice was as yet hardly felt.100 It was the growth of revenue practice into a substantial body of rules of evident authority reaching its zenith in the nineteenth

\footnotetext{
9820 Pharmaceutical Journal 405 (1889-90) (3rd series).

9919 Pharmaceutical Journal 651 (1888-89) ( $3^{\text {rd }}$ series).

100 For the early discussion of such issues, see Second Report and Minutes of Evidence before Committee of Public Accounts, HCPP (1897) (C. 196) viii 5, at pp. 5-12, and qq. 359-463, 878-1006.
} 
century that would demand the resolution of such issues in the next.101 Meanwhile, pragmatism was an acceptable imperative to the fiscal authorities in the nineteenth century as they sought to make an antiquated tax system function as efficiently as possible in the face of unprecedented government demands for public revenue. Revenue practice thus became, and remains, embedded in the modern fiscal landscape.

The context of executive equity, however, has changed significantly. Extra-statutory concessions continue, despite their being still regarded as a 'curiosity,'102 though they are fewer in number, more formally expressed, and more specific and narrow in their operation than in the nineteenth century. Tax practice is now published, its reasoning explained, and it is easily accessible. ${ }^{103}$ Tax guidance leaflets, statements of practice, tax bulletins on revenue interpretations and even instruction manuals are available to the public in print or on the internet. ${ }^{104}$ The interpretation of tax statutes has become more purposive. ${ }^{105}$ Because of the improvement in standards of legislative drafting, achieving fairness through the beneficial administrative interpretation and re-interpretation of uncertain provisions is no longer widespread and has reduced the volume of revenue practice considerably. Furthermore,

${ }_{101}$ Absalom v Talbot [1943] 1 All ER 589 at 598 per Scott LJ; Sir Alexander Johnston The Inland Revenue (George Allen \& Unwin Ltd, London, 1965) pp. 67-68; IRC v Frere [1965] AC 402 at 429 per Lord Radcliffe; Vestey $v$ IRC (No 2) [1979] 2 All ER 225 at 233 per Walton J; Vestey $v$ IRC (Nos 1 and 2) [1979] 3 All ER 976 at 984-5 per Lord Wilberforce; G.S.A. Wheatcroft, 'Law, Justice and Equity in Tax', in R.H.Code Holland and G. Schwarzenberger (eds) Law, Justice and Equity (Sir Isaac Pitman and Sons Ltd, London, 1967) p.90; D.C. Potter, 'Extra-Statutory Concessions', (1980) British Tax Review 270-272; Malcolm Gammie, '"Revenue Practice": A Suitable Case for Treatment?', (1980) British Tax Review 304-325; Robert Baldwin and John Houghton, 'Circular arguments: the status and legitimacy of administrative rules, (1986) Public Law 239-284; John Booth, The Inland Revenue...Saint or Sinner? (Coracle Publishing, Lymington, 2002), pp. 17-20, 145-75. See now $R$ (Wilkinson) $v$ IRC [2003] 1 WLR 2683, upheld [2005] 1 WLR 1718 (HL), which clarified the scope of the revenue authorities' administrative discretion to make concessions which departed from the letter of the law. It resulted in the revenue authorities' reviewing of all their extra-statutory concessions. Where a concession exceeded their proper discretion the intention was either to give them statutory expression or to abolish them.

102 David W. Williams and Geoffrey Morse, Davies Principles of Tax Law, $4^{\text {th }}$ edn (Sweet \& Maxwell, London, 2000), p. 34.

103 Accessibility of revenue practice began to improve in the latter part of the twentieth century: Malcolm Gammie, '"Revenue Practice": A Suitable Case for Treatment?', (1980) British Tax Review 304-325 at 306-309.

${ }^{104}$ http://www.hmrc.gov.uk/thelibrary/esc.htm

105 W.T. Ramsay Ltd v IRC [1982] AC 300 at 323 per Lord Wilberforce; Barclays Mercantile Business Finance Ltd v Mawson [2005] 1 AC 684. 
taxpayers are better informed, independent expert tax advice is available and the revenue authorities are subject to a far greater degree of scrutiny and accountability.

The executive equity of the nineteenth century has two enduring legacies. The first lies in the nature of tax legislation. Executive equity resulted primarily from a flawed legislative regime. As late as 1921 a judge observed in relation to a taxing Act that ' $[\mathrm{m}]$ ost of the operative clauses are unintelligible to those who have to pay the taxes'. ${ }^{106}$ Complexity of expression was largely inevitable, but there is evidence to suggest that the embedding of a widespread and generally effective revenue practice in the administration of tax law made legislators lazy ${ }^{107}$ and the revenue authorities arrogant. Certainly the revenue authorities took the view that they well knew the intention of Parliament, having been closely involved with the drafting of the legislation, ${ }^{108}$ and that they were ensuring fairness where Parliament had intended, but failed, to do so. Executive equity therefore served to mask the effects of slack legislation and allowed unsatisfactory legislative practices to endure. There was less incentive for the legislature to address the intractable problems of legislative drafting in tax in the face of an established, and largely effective, system of bureaucratic solutions. As a result, tax legislation remained profoundly unsatisfactory. Obscure, ambiguous or antiquated language, an absence of definition or coherent structure and the need to read most tax Acts in conjunction with a number of others, continued until well into the twentieth century. The unintelligibility and sheer bulk of tax legislation permeated tax law. Paradoxically, however, it was the sheer scope, depth and volume of revenue practice that highlighted the inadequacy of tax legislation, and the very existence of revenue practice

\footnotetext{
106 Brown v National Provident Institution [1921] 2 AC 222 at 257 per Lord Sumner. In 1948 Singleton J famously advised a taxpayer thus: 'I hope you will not trouble your head further with tax matters, because you seem to have spent a lot of time in going through these various Acts, and if you go on spending your time on Finance Acts and the like, it will drive you silly': Briggenshaw v Crabb (1948) 30 TC 331 at 333

107 G. S. A. Wheatcroft, 'The Attitude of the Legislature and the Courts to Tax Avoidance', 18 Modern Law Review 209-230 at 221 (1955).

108 Sir Alexander Johnston, The Inland Revenue (George Allen \& Unwin Ltd, London, 1965) p. 68.
} 
revealed and confirmed the appalling state of tax legislation as opaque and antiquated, and totally impenetrable. As Scott LJ observed in 1943, echoing the complaints of judges for over a hundred years, '[t]he fact that such extra-legal concessions have to be made to avoid unjust hardships is conclusive that there is something wrong with the legislation.' 109 This led to reforms in legislative drafting in tax and, ultimately, to the Tax Rewrite Project of the late 1990s whose object was to recast the direct tax legislation in clearer language and in a logical structure. ${ }^{110}$

The second enduring legacy of revenue practice in general and executive equity in particular is less tangible. The key role which it played in the administration of tax law, and its influence on its substance, served to reinforce the isolation of tax law within the institutions, theory, practice and public perceptions of English law. Tax law was already different to other branches of law with which practitioners had to deal in that it had a strong political and constitutional context and its mastery required a certain ease with accounts and figures. But what rendered it most distinctive, to the extent that it was regarded as an irregular species of law, was that it lay at the interface of law and administration and came to acquire a strongly administrative character. This was largely due to the admixture of administrative and judicial functions given by the legislation to the revenue boards and their various organs in order to fulfil their overall executive function of implementing the legislative regime of tax. To do so, they were given functions which, had they stood alone, would have been judicial in nature. The administrative process of implementing the tax regime subsumed otherwise clearly judicial functions. This was very obvious where the revenue authorities, directly or indirectly, exercised judicial powers of adjudication of tax disputes, since they regarded those powers as no more than part of the administrative

\footnotetext{
${ }^{109}$ Absalom v Talbot [1943] 1 All ER 589 at 598 per Scott LJ.

110 See http://www.hmrc.gov.uk/rewrite. For an insightful analysis of the problems relating to the nature of tax legislation, see John Avery Jones, 'Tax Law: Rules or Principles', 17 Fiscal Studies 63-89 (1996).
} 
process of assessing individuals to tax. Revenue practice incorporated other judicial functions such as statutory interpretation and parliamentary functions such as granting exemptions from statutory provisions, which made it difficult to isolate tax law from tax administration. In general, the executive implementation of tax law was so embedded into legal practices - adjudication, statutory interpretation and law making - that it obscured the usual boundaries between law and its administration and made it even more difficult to achieve any clarity of legal rights. The isolation of tax law due to its administrative character had profound consequences in that it undermined the authority of law and increased the power of the revenue authorities of the executive by lessening the controlling influence of legal norms.

Fairness is still at the centre of popular discourse as to tax policy, though the meaning is wider, including not only the traditional equality and consistency of treatment, but also simplicity, accessibility, neutrality in effect and competitiveness. ${ }^{111}$ The removal of loopholes and incentives which place a burden on some sections of the taxpaying public while allowing other sections to have a lighter liability also form part of what is now called tax justice and has become a global political concern. ${ }^{112}$ This kind of substantive fairness is now ensured principally through substantive legislation and judicial decisions. But the need for executive equity remains because the constitutional underpinning of tax law remains as robust as ever. It is still the case that an individual cannot be taxed other than by clear words in an Act of Parliament. This principle continues to shape the form and content of tax legislation. Taxation is, by nature, complicated and reflects the growing sophistication of commercial affairs. ${ }^{113}$ So while a complex legislative framework is inevitable, it necessarily

\footnotetext{
111 Richard Baron, 'Fairness and Justice in Tax Policy,' Institute of Directors, London 2009; House of Commons Hansard Debates, 12 March 2013, 'Tax Fairness.'

112 See for example the discussions in the G8 Summit in 2013: http://www.europeancouncil.europa.eu/home-page/highlights/g8-summit-promoting-global-fairness-through-trade,transparency-and-tax-compliance?lang=en

113 Report of the Royal Commission on Income Tax, HCPP (1920) (Cmd. 615) xviii 97 at para. 374.
} 
continues to give rise to unfairness at the margins of the code, which is addressed by adjusting its implementation through administrative action, namely through executive equity. It is clear that the judicial attitudes and practices developed in relation to the construction of statutes in general, and those of bureaucrats in relation to tax legislation in particular, served the same useful purpose: to introduce flexibility into the statutory system, to cure defects, to remedy injustice. Whereas the former has given rise to legal equity, so the latter evolved as a form of administrative equity. 